DOI: $10.19195 / 0080-3626.60 .8$

MACIEJ MATWIJÓW

\title{
„ACTA INTERREGNORUM”- - RĘKOPIŚMIENNE ZBIORY MATERIAŁÓW DOKUMENTUJĄCYCH DZIEJE BEZKRÓLEWI W RZECZYPOSPOLITEJ SZLACHECKIEJ W XVII I XVIII WIEKU*
}

Rękopiśmienne zbiory dokumentujące przebieg bezkrólewi lat 1632, 1696-1697 i 1733. Przyczyny i okoliczności ich tworzenia. Charakterystyka zachowanych egzemplarzy: ich zawartość, opracowanie redakcyjne i estetyka wykonania.

SŁOWA KLUCZOWE: bezkrólewie, Rzeczpospolita szlachecka, rękopis, materiały życia publicznego, książka rękopiśmienna

Wśród rękopiśmiennych zbiorów materiałów życia publicznego, tak licznie tworzonych w czasach staropolskich ${ }^{1}$, poczesne miejsce zajmują zbiory dokumentujące dzieje bezkrólewi. Obok akt rokoszów (poczynając od rokoszu Zebrzydowskiego, 1606-1608) i konfederacji stały się one inspiracją do tworzenia swego rodzaju rękopiśmiennych „wydawnictw źródłowych”, cechujących się przemyślaną konstrukcją i doborem materiałów. Bezkrólewia — od czasu ustalenia ich ostatecznego miejsca w ustroju prawnym Rzeczypospolitej w 1572 roku — stanowiły bowiem ożywiony okres życia publicznego. Było to wynikiem niespotykanej w innych krajach europejskich formy elekcyjności tronu, o który po śmierci panującego władcy ubiegać się mogli także kandydaci cudzoziemscy, a w ich wyborze miała prawo uczestniczyć cała szlachta (tzw. elekcja viritim). W czasie bezkrólewia, trwającego w XVII i XVIII wieku przeciętnie około 7-8 miesięcy (najdłużej w latach 1696-1697 — jeden rok, najkrócej w 1648 roku — sześć miesięcy)²,

* Niniejszy artykuł powstał w ramach projektu badawczego Zbiory materiałów życia publicznego jako typ książki rękopiśmiennej w czasach staropolskich XVII-XVIII w., finansowanego przez Narodowe Centrum Nauki.

1 Jedynym ujęciem tego zagadnienia z punktu widzenia księgoznawczego jest mój artykuł Z problematyki staropolskiej ksiązki rękopiśmiennej: kopiariusze i zbiory materiałów życia publicznego XVII-XVIII w., Roczniki Biblioteczne (55) 2011, s. 29-68.

2 Bezkrólewie trwało od chwili śmierci króla do w zasadzie chwili zaprzysiężenia przez elekta paktów konwentów. Koronacja, która formalnie kończyła bezkrólewie i uprawomocniała 
odbywały się dwa sejmy walne (konwokacyjny i elekcyjny), które podejmowały zasadnicze decyzje co do jego przebiegu i organizacji państwa aż do wyboru nowego króla, oraz sejmiki ziemskie, na których szlachta wybierała posłów na sejmy, zawiązywała konfederacje wojewódzkie i podejmowała wszelkie decyzje dotyczące spraw lokalnych. Co jednak najważniejsze, podczas bezkrólewia szlachta — jako potencjalni elektorzy nowego króla — stawała się obiektem aktywnych zabiegów kandydatów do tronu i popierających ich stronnictw w celu zdobycia jej głosów w akcie elekcyjnym. Powodem nieprzewidzianych przez prawo komplikacji były rozdwojone wyniki elekcji (doszło do nich w latach 1575, 1587, 1697 i 1733), kiedy zgromadzona na polu elekcyjnym szlachta nie potrafiła uzgodnić wspólnego stanowiska i wybierała dwóch królów, niekiedy nawet w dwóch osobnych zgromadzeniach (miało to miejsce w 1733 roku). Zazwyczaj o ostatecznym umocowaniu się jednego $\mathrm{z}$ dwóch elektów decydowała po prostu szybsza koronacja, lecz niekiedy — jak w latach 1733-1736 — dochodziło nawet do, w pełnym tego słowa znaczeniu, wojny domowej, której kres przyniosło dopiero militarne zwycięstwo jednej ze stron i formalne zrzeczenie się przez pokonanego kandydata swoich praw do tronu.

To przyspieszone tempo życia publicznego znajdowało swój wyraz w zwiększonej podaży akt urzędowych (uniwersałów, instrukcji i uchwał sejmikowych oraz sejmowych), publicystyki politycznej, literackich utworów okolicznościowych oraz innej dokumentacji życia publicznego o charakterze nieoficjalnym, lecz odnoszących się bezpośrednio do rozgrywających się wydarzeń, jak listy, mowy, manifestacje, diariusze obrad sejmikowych i sejmowych. W większości te dokumenty funkcjonowały od momentu swego powstania w postaci rękopiśmiennej, chociaż i tutaj druk zdobywał stopniowo coraz szersze zastosowanie. Dotyczyło to przede wszystkim akt urzędowych, chociaż nie wszystkich — z reguły nie były drukowane akta sejmikowe oraz, oczywiście, korespondencja urzędowa. Z druku korzystała też publicystyka polityczna, co należy wiązać z zaangażowaniem się w jej tworzenie i rozpowszechnianie ośrodków zagranicznych stojących za popieranymi przez siebie kandydatami do tronu ${ }^{3}$.

Tego rodzaju dokumentacja życia publicznego rejestrowana była najczęściej w odpisach w najróżniejszych rękopiśmiennych miscellaneach i silvae rerum, spisywanych i tworzonych na bieżąco przez szlachtę i mieszczaństwo. Ich twórcy z reguły nie mieli ambicji i dążeń ani do ich kompletnej rejestracji, ani do nadania im usystematyzowanego układu. Jednocześnie obok tych tworzonych dorywczo

władzę króla-elekta, miała w praktyce znaczenie raczej symboliczne i mogła odbywać się w wiele miesięcy po elekcji bez uszczerbku dla uprawnień króla-elekta (najdłuższa zwłoka w tej mierze miała miejsce w przypadku Jana III Sobieskiego, którego koronacja odbyła się po półtora roku od elekcji).

${ }^{3}$ Duży udział drukowanej publicystyki wydaje się charakterystyczny właśnie dla okresów bezkrólewi, lecz ponieważ tematyka ta nie stała się nigdy przedmiotem szczegółowych badań, nie sposób w tym miejscu przywołać jakichkolwiek danych liczbowych. 
zbiorów powstawały również dzieła zawierające w szerszym lub mniejszym wyborze najważniejsze, najbardziej rozpowszechnione lub reprezentatywne materiały, które uporządkowane według różnych kryteriów tworzyć miały swego rodzaju dokumentację dziejów bezkrólewi. Wyraźnie sygnalizowano to w ich tytułach, określając je najczęściej mianem ,,acta interregni”. Wszystkie tego rodzaju zbiory tworzone były bez myśli o druku i funkcjonowały w obiegu społecznym jedynie w postaci rękopiśmiennej, co czyniło z nich w XVII i XVIII wieku wzorcowe niemal przykłady książki rękopiśmiennej ${ }^{4}$. Nie wykluczało to oczywiście obecności w nich tekstów drukowanych, lecz były to przypadki rzadkie — przeważnie teksty te albo przepisywano $\mathrm{w}$ całości, albo w ogóle rezygnowano $\mathrm{z}$ ich zamieszczania ze względu na ich powszechną dostępność w druku 5 . Trzeba też wyraźnie zaznaczyć, że nie miały one charakteru dokumentacji archiwalnej jak choćby w wypadku kopiariuszy kancelaryjnych, lecz były w pełni przemyślanym efektem indywidualnej twórczości intelektualnej ich redaktorów — osób czuwających nad doborem i układem tworzących je materiałów.

Co prawda w trakcie bezkrólewi w XVII wieku wychodziły drukiem Acta interregni, lecz miały one nieco inny charakter od swego rękopiśmiennego odpowiednika, albowiem zawierały jedynie najważniejsze akta urzędowe, to jest uniwersał prymasa zwołujący sejmiki przedkonwokacyjne i wyznaczający termin sejmu konwokacyjnego, akt konfederacji generalnej uchwalony na tym sejmie, $P o-$ rzadek na sejmie walnym elekcyjej (wraz z dołączonymi do niego innymi aktami sejmu elekcyjnego, takimi jak artykuły paktów konwentów, przysięga nowo wybranego króla na pacta conventa i ,suffragia” szlachty na elekcji, które mogły być drukowane także osobno), a od 1697 roku także Oznajmienie króla nowoobranego na sejmie elekcyi... ${ }^{6}$ Wyraźnie też od tego rodzaju zbiorów należy odróżnić kroni-

${ }^{4}$ Od tych ,,actorum interregnorum” o zasadniczo ujednoliconej zawartości i będących przedmiotem szerokiego nieraz rozpowszechniania należy odróżnić „acta interregnorum” tworzone przez indywidualnych kolekcjonerów wyłącznie na swój użytek, czego przykładem może być zbiór materiałów dotyczących bezkrólewia 1733 roku, stworzony przez generała wojsk koronnych Michała Stanisława Korwina Kamińskiego (Biblioteka Uniwersytetu Warszawskiego, dalej: BUW, rkps akc. 62).

5 Zob. dalej, s. 199.

${ }^{6}$ Zob. Karol ESTREICHER, Bibliografia polska, t. 12, Kraków: Akademia Umiejętności 1891, s. 31-32; Akta z czasów bezkrólewia 1632 roku. Wydaw. Władysław Sobociński, Poznań: Księgarnia Akademicka 1949, s. 12, 16-40; Kazimierz BUDZYK, Bibliografia konstytucyj sejmowych XVII wieku w Polsce, Wrocław: Wydaw. Zakładu Narod. im. Ossolińskich 1952, s. 57-62, 79-82, 104-107, 113-115, 128-136. Akta te dla poszczególnych bezkrólewi nie wychodziły bezpośrednio po ich zakończeniu w postaci wspólnej, jednej edycji, lecz pojedynczo w trakcie bezkrólewia, każdy akt lub ich zestaw osobno. Zaopatrzone we wspólną całemu takiemu zbiorowi kartę tytułową (poprzedzającą otwierający całą dokumentację uniwersał prymasa lub dodrukowaną osobno), dopiero po skompletowaniu akta te tworzyć miały całość wydawnictwa, zob. Acta interregni... post mortem... Sigismundi Tertii regis Poloniae... 1632 [Kraków: A. Piotrkowczyk 1632-1633], egzemplarz w zbiorach starych druków Biblioteki Zakładu Narodowego im. Ossolińskich (dalej: 
karsko-pamiętnikarskie opisy przebiegu bezkrólewi, których najbardziej znanym przykładem jest powstałe pod koniec XVI wieku dzieło Świętosława Orzelskiego Bezkrólewia ksiag ośmioro 1572-1576 (Interregni Poloniae libri VIII), w czasach staropolskich również rozpowszechniane wyłącznie w postaci rękopiśmiennej ${ }^{7}$ i niekiedy tytułowane niezbyt właściwie także jako Acta interregni post obitum Sigismundi Augusti regis Poloniae ${ }^{8}$.

Nie wszystkie bezkrólewia doczekały się swoich zbiorów dokumentacyjnych, o czym decydowały zarówno towarzysząca bezkrólewiom dramaturgia wydarzeń politycznych, jak i znalezienie się osoby lub osób zdolnych do podjęcia się takiej pracy redakcyjnej. Tym przede wszystkim można tłumaczyć, że tego typu zbiory powstały właściwie jedynie dla bezkrólewi lat 1632, 1696-1697 i 1733. O ile powstanie takich zbiorów dla dwóch ostatnich było uzasadnione burzliwym ich przebiegiem i rozdwojonymi wynikami elekcji, a w efekcie tego dalszymi niepokojami wewnętrznymi angażującymi uwagę znacznej części społeczeństwa szlacheckiego, o tyle dla akt bezkrólewia 1632 roku tym czynnikiem mogła być jedynie waga rozstrzyganych w tym okresie kwestii prawnoustrojowych państwa. Bezkrólewie to miało przebieg niezwykle spokojny, a jego wynik — wybór najstarszego syna Zygmunta III Wazy, Władysława Zygmunta — z góry przewidziany. Spośród pozostałych bezkrólewi, których w XVII-XVIII wieku było łącznie siedem, najbardziej dla nas zaskakujące jest niepowstanie podobnego zbioru dla bezkrólewia lat 1668-1669, budzącego przecież ogromne zainteresowanie w kraju i za granicą ze względu na silne zaangażowanie w nie kilku państw europejskich, jego niespodziewany wynik i ferment polityczny, jaki ogarnął wówczas szlachtę. Nie można natomiast tego samego powiedzieć o bezkrólewiach lat 1648, 1673-1674 i 1763-1764, podczas których rywalizacja o polską koronę przebiegła bez większych konfliktów, co z pewnością nie skłaniało do tworzenia dzieł dokumentujących ich przebieg.

Autorstwo tych zbiorów i czas ich powstania nie są w większości dokładnie znane. Tylko w przypadku jednej z redakcji akt bezkrólewia 1632 roku znamy twórcę, którym był - imiennie wskazany w tytule dzieła - krajczy koronny Jakub Sobieski (1590-1646) - wybitny mówca, parlamentarzysta (nb. marszałek sejmu elekcyjnego 1632 roku) i zamiłowany kronikarz wydarzeń epoki ${ }^{9} . \mathrm{Z}$ tego

BZNiO), w którym umieszczono także uchwały dwóch najważniejszych sejmików koronnych: proszowickiego województwa krakowskiego i średzkiego województw poznańskiego i kaliskiego.

7 Zob. Edward KUNTZE, Przedmowa, [do:] Świętosława Orzelskiego bezkrólewia ksiag ośmioro 1572-1576. Wydaw. E. Kuntze, Kraków: Akademia Umiejętności 1917, s. XXX-XXXVI.

8 Rękopisy Biblioteki Kórnickiej (dalej: BK) nr 274, Biblioteki Załuskich nr 364 (w Cesarskiej Bibliotece Publicznej w Petersburgu nr Lat. F. IV. 33, zniszczony w 1944 r.) i BZNiO nr 3551.

9 „Acta interregni po śmierci króla jmci Zygmunta Trzeciego i diariusz aktu i sejmu koronacyi Władysława IIII, w domu jmci pana Sobieskiego krajczego koronnego pisany i przez jmci samego acurate trutinowane anno domini 1632 ultima die aprilis". Dzieło to i pozostały dorobek kronikarski i dokumentacyjny Sobieskiego omówił pokrótce Józef DŁUGOSZ, Jakub Sobieski 
samego źródła wiemy także, że do tworzenia swego dzieła przystąpił on już w trakcie bezkrólewia, a zakończył je zapewne wkrótce po odnośnych wypadkach dziejowych.

Pozostałe tworzone były anonimowo, co jest w ogóle cechą charakterystyczną dla tego rodzaju zbiorów. Lakoniczność lub całkowity brak w większości z nich jakichkolwiek uwag i informacji odredakcyjnych nie daje żadnych wskazówek pozwalających na ustalenie ich autorstwa. $Z$ dużym prawdopodobieństwem możemy jednak przyjąć, że redagowane one były albo jeszcze w trakcie, albo bezpośrednio po zakończeniu poszczególnych bezkrólewi w środowisku urzędniczym zatrudnionym w centralnych organach administracji państwowej. Naturalnymi ośrodkami ich tworzenia były oczywiście obie kancelarie (wielka i mała) — koronna i litewska, w których z racji pełnionych funkcji administracyjnych skupiał się przepływ różnego rodzaju akt i materiałów, nie tylko o charakterze urzędowym ${ }^{10}$. Sprzyjała temu także działalność niektórych kanclerzy zabiegających o gromadzenie tego typu materiałów na własne potrzeby lub z racji zainteresowań dokumentacyjnych — w XVII i XVIII wieku duże ich zbiory zgromadzili m.in. podkanclerzy i następnie kanclerz wielki koronny Jan Szembek (zm. 1731 roku $)^{11}$ oraz biskup płocki i warmiński Andrzej Chryzostom Załuski (zm. 1711), kanclerz wielki koronny od 1702 roku, który zgromadzoną przez siebie dokumentację opublikował w dziele Epistolae historico-familiares (t. 1-3, Brunsbergae 1709-1711 i pośmiertnie t. 4, Wratislaviae 1761) ${ }^{12}$. W kancelariach i Metryce Koronnej pracowali też urzędnicy, którzy z racji dostępu do materiałów i własnych zainteresowań prywatnie zajmowali się tworzeniem różnego rodzaju zbiorów dokumentacyjnych, jak np. Stefan Kazimierz Hankiewicz (zm. przed 1701 rokiem) ${ }^{13}$ i Hieronim Pinocci $(1612-1676)^{14}$, a także dostarczaniem zainteresowanym osobom informacji o bie-

1590-1646 parlamentarzysta, polityk, podróżnik i pamiętnikarz, Wrocław: Wydaw. Uniwersytetu Wrocławskiego 1989, s. 158-163.

10 Wojciech KRAWCZUK, Metrykanci koronni. Rozwój registratury centralnej od XVI do XVIII wieku, Kraków: Tow. Wydawnicze „Historia Iagellonica” 2002, s. 48. Warto przypomnieć, że w kręgu kancelarii koronnej powstało w połowie XVI w. największe w czasach staropolskich dzieło dokumentacyjne - „Acta Tomiciana” Stanisława Górskiego.

11 Rola kancelarii koronnej na tym polu, jako ośrodka dokumentującego i uczestniczącego w kulturze książki rękopiśmiennej XVII-XVIII w., nie doczekała się jak dotąd opracowania. Dotyczy to także działalności na tym polu kanclerzy koronnych, zaangażowanych w gromadzenie materiałów życia publicznego.

12 Bogate materiały życia publicznego z lat 1696-1697, zgromadzone przez A.Ch. Załuskiego, uległy zniszczeniu w 1944 r. wraz z innymi rękopisami Biblioteki Załuskich (w Cesarskiej Bibliotece Publicznej w Petersburgu znajdowały się one m.in. pod sygn. Pol. F. IV. 112).

13 Jego dziełem są miscellanea z czasów panowania Zygmunta III, Władysława IV i Jana Kazimierza (do 1655 r.), BK, nr 991.

14 O zbiorze ,akt publicznych” Pinocciego zob. Karolina TARGOSZ, Hieronim Pinocci. Studium z dziejów kultury naukowej w Polsce w XVII wieku, Wrocław 1967: Wydaw. Zakład Narod. im. Ossolińskich 1967, s. 99, 176-185. 
żących wydarzeniach politycznych, jak np. metrykant koronny Andrzej Cichocki (zm. w 1752 roku) ${ }^{15}$. W okresie bezkrólewi rolę kancelarii koronnej i litewskiej, w części przynajmniej, przejmowały kancelarie arcybiskupów gnieźnieńskich prymasów, w których rękach, jako „interreksów”, znajdowało się kierownictwo polityki państwowej. Z tego względu w ich kancelariach gromadzona była najważniejsza dla funkcjonowania państwa w okresie bezkrólewia dokumentacja, mogąca być podstawą do zredagowania tego rodzaju zbiorów, i tam też zatrudniony był personel, który takiej pracy mógł się podjąć i podejmował ${ }^{16}$.

Najprawdopodobniej właśnie z kancelarią prymasa Jana Wężyka należy wiązać powstanie drugiej redakcji akt bezkrólewia $1632 \mathrm{roku}^{17}$. Przemawia za tym sam dobór materiałów — ściśle związany z czynnościami urzędowymi prymasa. Co do zbioru akt lat $1696-1697^{18}$, to jego wielkość oraz bogactwo, różnorodność i sposób zredagowania materiału, niemający pod względem konstrukcji analogii w innych tego rodzaju zbiorach, nie pozwala na udzielenie tutaj jednoznacznej odpowiedzi — osoby redaktora, a raczej redaktorów tego zbioru, można widzieć zarówno wśród urzędników którejś z kancelarii koronnej, jak i w środowisku kancelarii prymasowskiej Michała Radziejowskiego. Prymas ten podjął wówczas bardzo aktywną działalność publiczną w pełnym tego słowa znaczeniu nie tylko jako zwierzchnik państwa w okresie bezkrólewia, lecz także jako przywódca obozu politycznego, mocno zaangażowany po stronie jednego z kandydatów do tronu (najpierw był to królewicz Jakub Ludwik Sobieski, potem François Louis de Bourbon, książę de Conti). Przemawiać za tym może także fakt, że prawdopodobnie w kręgu prymasowskim powstało na przełomie XVII/XVIII wieku kilka innych zbiorów materiałów życia publicznego ${ }^{19}$. Z kolei jednak hipotezy o powstaniu tego zbioru w otoczeniu prymasa nie potwierdza sam dobór materiałów, który mimo względnej obfitości akt związanych z Radziejowskim wcale nie wyczerpu-

15 Kazimierz MALISZEWSKI, Obraz świata i Rzeczypospolitej w polskich gazetach rękopiśmiennych z okresu późnego baroku. Studium z dziejów ksztattowania się i rozpowszechniania sarmackich stereotypów wiedzy i informacji o „Theatrum mundi”, Toruń: Uniw. Mikołaja Kopernika 1990, s. 31.

16 Świadectwem działalności dokumentacyjnej ośrodka prymasowskiego jest np. kopiariusz akt politycznych prymasa Macieja Łubieńskiego z lat 1648-1649, znany z fragmentarycznej edycji Korespondencja prymasa i senatu z czerwca-listopada 1648 roku. Bezkrólewie, Chmielnicki, elekcja. Oprac. ks. Stanisław Librowski, Archiwa, Biblioteki i Muzea Kościelne (55) 1987, s. 203-302. Niestety tematyka działalności urzędowej prymasów jako kierowników państwa w okresie bezkrólewi i funkcjonowania ich kancelarii nie doczekała się jak dotąd opracowania.

17 „Acta interregni Anni Domini 1632 post mortem serenissimi Sigismundi III regis Poloniae”, Archiwum Archidiecezjalne w Poznaniu, zbiór Augusta Gorzeńskiego (dalej: ZAG), nr 1.

18 „Interregnum [post mortem] Joannis III”, wykaz egzemplarzy zob. przyp. 30 i 31.

19 Dotyczy to odpisów nowin i różnych akt publicznych z lat 1702-1704 (Biblioteka Czartoryskich w Krakowie, dalej: BCz., nr 526, 527 i 532), które jak świadczą wzmianki w tekście, sporządzone zostały w Łowiczu, a więc mieście będącym jedną z rezydencji prymasa Radziejowskiego. 
je jego bogatej i ważnej dokumentacji politycznej z tego okresu i nie prezentuje też profrancuskiej opcji politycznej ${ }^{20}$. $Z$ całą pewnością zbiór ten nie wykazuje większego pokrewieństwa z Epistolis historico-familiaribus Andrzeja Chryzostoma Załuskiego, co raczej wyklucza udział biskupa warmińskiego w jego powstaniu. Nie można natomiast całkowicie wykluczyć jego powstania w którymś z miast pruskich — w grę wchodzić tu może przede wszystkim Gdańsk ${ }^{21}$, a także Toruń, gdzie bogatą dokumentację z okresu panowania Augusta II zgromadził i kilkanaście podobnego rodzaju zbiorów zredagował tamtejszy poczmistrz Jakub Kazimierz Rubinkowski ${ }^{22}$. Za taką supozycją przemawiać może zwłaszcza nietypowy dla Polski sposób zredagowania zebranego materiału, niewykluczone, że oparty na wzorach zagranicznych. $Z$ doboru materiałów możemy wnioskować, że zbiór ten powstał zapewne zaraz wkrótce po elekcji Augusta II, natomiast z posłowia zamieszczonego na końcu tego zbioru wiadomo, że jego redaktor lub redaktorzy mieli już przygotowane materiały dotyczące wypadków z kolejnych lat 1698 i 1699, z których planowali przygotowanie kolejnego tomu swego „wydawnictwa",23.

Nieznane jest również autorstwo kolejnego zbioru materiałów dotyczącego lat 1733-1736. Wydaje się, że w ogóle trudno tutaj mówić o jednym redaktorze i jednym ośrodku redakcyjnym, gdyż mamy tu raczej do czynienia ze zjawiskiem kształtowania się jego pełnej wersji stopniowo i przez różne osoby poprzez uzupełniania i rozbudowywania pierwotnej redakcji powstałej zapewne w otoczeniu prymasa Teodora Potockiego w 1733 roku $^{24}$. Prymas ten - wzorem swoich poprzedników - w wydarzeniach bezkrólewia odegrał bardzo aktywną rolę jako przywódca obozu popierającego kandydaturę Stanisława Leszczyńskiego. Redaktorem tej pierwotnej redakcji mógł być jego sekretarz, starosta nieszawski Józef Mogilnicki (zm. w 1764 roku), mający z tej racji bezpośredni dostęp do

20 Zob. odpis akt politycznych M. Radziejowskiego z lat 1696-1697 (razem ok. 180 dokumentów piśmienniczych), BUW, rękopis nr 78, s. 317-617.

21 Problematyka gromadzenia materiałów życia publicznego w Gdańsku — zarówno przez tamtejszą radę miejską w związku z jej działalnością urzędową, jak i prywatnego dokumentowania wydarzeń epoki przez przedstawicieli mieszczaństwa — nie doczekała się jak dotąd w nauce polskiej opracowania.

${ }^{22}$ Bardzo bogate rękopiśmienne zbiory Rubinkowskiego zostały niemal w całości zniszczone w 1944 r. wraz z większością rękopisów Biblioteki Załuskich.

23 „Interregnum [post mortem] Joannis III”, BCz., nr 445, s. 629; Lwowska Naukowa Biblioteka NAN Ukrainy im. W. Stefanyka (dalej: LNB), Zbiór Ossolineum (dalej: ZO), nr 256, k. 747.

${ }^{24} \mathrm{Na}$ ewentualność powstania tego zbioru w kręgu kancelarii prymasa Potockiego zwrócono już uwagę w drukowanym katalogu Biblioteki Ordynacji Krasińskich, zob. Wykaz inwentarzowy rękopisów Biblioteki Ord. Krasińskich, nie objętych katalogiem Fr. Pułaskiego, [w:] F. Pułaski, Opis 815 rękopisów Biblioteki Ord. Krasińskich, Warszawa: nakł. Funduszu Świdzińskich 1915, dodatek, s. [19]. 
wszystkich akt publicznych będących w posiadaniu swego chlebodawcy ${ }^{25}$. Jako autora tego zbioru wskazał go wprost Jan Daniel Janocki w swoim katalogu rękopisów Biblioteki Załuskich, za czym poniekąd przemawiać może także zaopatrzenie kilku egzemplarzy tego zbioru w jego krótki tekst, wyjaśniający okoliczności pierwszych dni bezkrólewia, stanowiący jakby wstęp do zamieszczonych dalej akt ${ }^{26}$. Jak się zdaje, obok niego (w okresie gdy wraz z prymasem Potockim znajdował się on w oblężonym Gdańsku, a potem w latach 1734-1735 w niewoli rosyjskiej) dużą rolę w kształtowaniu tego zbioru odegrać mogło środowisko kancelarii marszałka wielkiego koronnego Józefa Wandalina Mniszcha, skupione na jego dworze w Laszkach Murowanych na Rusi Czerwonej. Przemawia za tym znajdujący się w jednym z rękopisów kolekcji mniszchowskiej oryginał relacji księdza St. Germain o śmierci Augusta II, którego odpis wszedł potem do kolejnych redakcji tego zbioru ${ }^{27}$, a także charakter niektórych z włączonych do tego zbioru materiałów, związanych bezpośrednio z Mniszchem i województwem ruskim.

Charakterystyczne dla akt bezkrólewia i innych tego rodzaju zbiorów akt tworzonych w celu dokumentowania ważnych wydarzeń politycznych jest występowanie ich $\mathrm{w}$ wielu egzemplarzach, często niejednolitych pod względem treści i układu materiałów, co było wynikiem specyfiki rękopiśmiennego ich powielania, dowolnego modyfikowania doboru i układu materiałów, zgodnie z potrzebami i możliwościami kopistów lub zleceniodawców. Jeśli idzie o sposób rozpowszechniania, mamy tutaj do czynienia zarówno ze zjawiskiem odpisywania tych akt jeden od drugiego „systemem łańcuszkowym”, i to nawet w dość dużym odstępstwie czasowym, jak $\mathrm{i}$ - co jest dla nas szczególnie interesujące - $\mathrm{z}$ ich powielaniem $\mathrm{w}$ jednym ośrodku pisarskim i w jednym czasie.

W przypadku akt bezkrólewia 1632 roku znanych jest sześć egzemplarzy zbioru zredagowanego przez Jakuba Sobieskiego, z których do naszych czasów zachowało się pięć egzemplarzy ${ }^{28}$, oraz zaledwie dwa egzemplarze tzw. redakcji

25 O jego działalności jako sekretarza prymasa Potockiego i jako domniemanego dokumentalisty wydarzeń epoki nie wspomina nic jego biogram w Polskim słowniku biograficznym (t. 21, Wrocław: Wydaw. Zakład Narod. im. Ossolińskich 1976, s. 562-563) pióra Zofii Zielińskiej.

26 Jan Daniel JANOCKI, Musarum sarmaticarum specimina nova, Vratislaviae: W. Korn 1771, s. 115; „Praefatio ad acta interregni przez w. jmp. Mogilnickiego, starostę nieszawskiego napisane", BZNiO, nr 6611, s. VII-IX. Ten sam tekst, jednak bez tytułu i bez wymienienia nazwiska autora, także w BUW, nr 358 s. 15-16, i w Archiwum Głównym Akt Dawnych w Warszawie (dalej: AGAD), w Archiwum Komierowskich (dalej: AK) nr 62/82, s. 16-17. Przedmowa ta znajduje się także w rękopisie BZNiO nr 302, lecz ponieważ ten egzemplarz jest bezpośrednim odpisem z rękopisu BZNiO nr 6611, nie należy go traktować jako źródła o równorzędnym znaczeniu.

27 Rękopis BZNiO nr 3577, k. 294-295.

28 Są to rękopisy: AGAD, Archiwum Publiczne Potockich (dalej: APP) nr 303; AGAD, Zbiór Branickich z Suchej nr 137/161 (odpis z XVIII w.); BCz. nr 363 i nr 364 (prawdopodobnie odpis z końca XVII w., niedokończony); Biblioteka Jagiellońska w Krakowie (dalej: BJ) nr akc. 19/52. Zniszczony w 1944 r. został egzemplarz pochodzący z Biblioteki Załuskich w Warszawie (nr 365, 
„prymasowskiej” w dwóch odmiennych wersjach — pełnej i fragmentarycznej ${ }^{29}$. Egzemplarze „Actorum interregni” J. Sobieskiego pochodzą głównie z lat 30. i 40. XVII wieku i jak się zdaje, są niezależnymi od siebie kopiami. Pod względem doboru i układu materiałów są one niemal identyczne, co można wiązać z jednolitą i dopracowaną kompozycją autorską tego dzieła, niepozwalającą na swobodne jej zmienianie.

W przypadku akt bezkrólewia 1696-1697 znanych jest aż 17 ich egzemplarzy, z czego $15^{30}$ zachowało się do naszych czasów; pozostałe dwa, pochodzące ze zbiorów Biblioteki Załuskich, uległy zniszczeniu w Warszawie w 1944 roku $^{31}$. Co ważne, zdecydowana większość z nich, albowiem aż 12, pochodzi z przełomu XVII/XVIII wieku. Egzemplarze te pod względem zawartości i układu materiałów są w zasadzie bardzo do siebie zbliżone, z nielicznymi tylko wyjątkami. Różnice między nimi polegają na pewnych zmianach w doborze materiałów ${ }^{32}$, przestawiania ich kolejności oraz różnych poprawkach redakcyjnych (zmiany tytułów, uzupełnienia dat itp.). Przyczyną tego mogły być najzwyklejsze omyłkowe opuszczenia niektórych dokumentów przy przepisywaniu, jak też tworzenie wersji poprawionych i uaktualnionych o nowe materiały, wcześniej redaktorom niedostępne ${ }^{33}$, niewykluczone są także względy utylitarne lub chęć dostosowywania

w katalogu Musarum sarmaticarum Janockiego umieszczony pod nr. 93), który w Cesarskiej Bibliotece Publicznej w Petersburgu nosił sygnaturę Pol. IV. F. 93.

29 Wersja „pełna” w rękopisie ZAG nr 1; wersja „skrócona” w rękopisie BK nr 345.

30 Są to rękopisy: AGAD, Archiwum Radziwiłłów (dalej: AR), dział II, nr 33; ibidem, APP, nr 54; LNB, zbiór Biblioteki Baworowskich (dalej: BB), nr 66; ibidem, ZO, nr 256; BJ, nr 3522; ibidem, nr 6306; BK, nr 398; ibidem, nr 1200; Biblioteka Narodowa w Warszawie (dalej: BN), nr 6646; BCz., 2 tomy, nr 441 i 442; ibidem, nr 445 (fragment zawierający jedynie drugą część zbioru); ibidem, nr 3586 (z licznymi ubytkami); Archiwum Narodowe w Krakowie, Archiwum Sanguszków (dalej AS),nr 271; Biblioteka Gdańska PAN (dalej: BG), nr 1529. Najprawdopodobniej z tym zbiorem mamy do czynienia także w przypadku rękopisu z Archiwum Mniszchów z Wiśniowca w Centralnym Państwowym Archiwum Historycznym w Kijowie (fond 250, dział 3, nr 33), za czym przemawia zarejestrowana w opisie inwentarzowym jego tematyka, zakres chronologiczny i objętość (609 kart!). Lista powyższa zapewne nie jest pełna, gdyż dalsza kwerenda może ujawnić kolejne egzemplarze.

31 „Acta interregni po śmierci Jana III 1696-1697” i „Interregnum anni 1696 d. 17 julii”, w Bibliotece Załuskich zapewne nr 366 i 367, w Cesarskiej Bibliotece Publicznej w Petersburgu występowały pod sygn. Pol. F. IV. 38 i Razn. F. IV. 32. Ich dokładna treść nie jest znana, lecz jak wynika z zarejestrowanych w katalogach i inwentarzach ich tytułów, można je z dużym prawdopodobieństwem utożsamiać z odnośnymi aktami bezkrólewia.

32 Te zmiany są tak indywidualne dla każdego z egzemplarzy, że trudno wychwycić tutaj jakieś prawidłowości. Np. egzemplarze BB nr 66 i BJ nr 3522 reprezentują redakcję tekstu, w której brakuje np. pięciu listów królowej Marii Kazimiery do różnych osób z czerwca 1696 r., lecz uzupełnione są m.in. o bardzo wówczas popularne wiersze satyryczne: Diwinacja Apollina sarmackiego o Szatonoffie pośle francuskim i Lament madame Ptyzanowej, których z kolei nie ma w innych egzemplarzach (np. BK nr 398 i ZO nr 256) itp.

33 Wydaje się, że jedną z najwcześniejszych wersji jest egzemplarz BB nr 66 (jest ona najuboższa pod względem zawartości nawet o ok. 25\% w stosunku do najpełniejszych wersji, nie za- 
zawartości zbiorów do oczekiwań potencjalnych odbiorców. Jednak mimo tych zmian wszystkie te egzemplarze zachowują pewną ustaloną formułę kompozycyjną. Uwagi powyższe są ważne ponieważ w przypadku tego zbioru mamy do czynienia ze zmianami autorskimi, wprowadzanymi bezpośrednio przez redaktora (redaktorów) zbioru, albowiem pochodzące z przełomu XVII/XVIII wieku egzemplarze są w dużej części efektem zorganizowanej „produkcji” — udało się zidentyfikować aż co najmniej siedem ich egzemplarzy, sporządzonych według jednolitego schematu kompozycyjnego i jedną ręką, co wskazuje że tworzone były one na zamówienie i w ten sposób rozpowszechniane ${ }^{34}$. Co do komercyjnego charakteru przedsięwzięcia nie pozostawia wątpliwości posłowie zamieszczone w niektórych późniejszych egzemplarzach zbioru, będące w istocie odezwą mającą zachęcić zleceniodawcę do zamówienia i sfinansowania kolejnego tomu dzieła dotyczącego wydarzeń lat 1697-169935. Tej dbałości o jednolitą formułę nie widać niestety w ich dwóch późniejszych kopiach z połowy XVIII wieku ${ }^{36}$, w których opuszczono bardzo wiele dokumentów piśmienniczych — w przypadku jednego z tych rękopisów był to zabieg zresztą w pełni zamierzony, połączony z przeróbką konstrukcji rękopisu.

Równie obficie prezentują się akta bezkrólewia i wojny domowej lat 1733-1736. Ich liczbę można szacować na 20 egzemplarzy (w tym trzy już nieistniejące) ${ }^{37}$, przy czym w odróżnieniu od akt poprzedniego bezkrólewia prezentują one nieco większą wariantywność, lecz również nienaruszającą zasadniczej kompozycji zbioru. Można to wiązać z zasygnalizowanym wyżej specyficznym charakterem tworzenia tych zbiorów, podlegających licznym modyfikacjom z powodu przeciągającej się aż do początków 1736 roku walki o tron polski i pojawianiem się nieustannie nowych materiałów uzupełniających zbiór, a także usuwaniem pewnych dokumentów lub wprowadzaniem innych w zależności od własnych potrzeb i upodobania, niekiedy także z pobudek utylitarnych czy ekonomicznych (np. rezygnowanie z zamieszczania w nich odpisów diariuszy sejmowych, które dostępne były w wersjach drukowanych). Niewykluczone też, że mamy tutaj do czynienia ze zjawiskiem kompilowania zbiorów z kilku różnych kopiariuszy „cząstkowych”,

wiera posłowia ani spisu treści), nieco późniejszy, zapewne z 1698 r., jest egzemplarz z BJ nr 3522 (ma on nieco bardziej rozbudowane od poprzedniego posłowie i jest nieco bogatszy pod względem zawartości) - oba te egzemplarze mają natomiast podobny układ materiałów (zasadniczo według chronologii). Za najpóźniejsze można uznać egzemplarze AR II nr 33, BCz. nr 441, 442, 445 oraz ZO nr 256, które mają najbardziej rozbudowaną zawartość, dopracowany indeks zawartości oraz posłowie napisane ok. 1699 lub $1700 \mathrm{r}$.

34 Są to egzemplarze: AR II nr 33; BCz. nr 445; ibidem, nr 3586; AS nr 271; BG nr 1529; BB nr 66; BJ nr 3522.

35 Jak bez ogródek stwierdzono w tej odezwie — zebrane przez siebie materiały gotów był pisarz lub redaktor tego dzieła „W manuskrypt drugi przepisać, jeżeli pańska curiositas hojnością do tej przychęci pracy i rozkazaniem".

36 Rękopisy BN nr 6646 i APP nr 54.

37 Zob. niżej. 
zawierających fragmentaryczne zbiory akt — na ślad istnienia takowych jednak nie natrafiono.

Trudno stwierdzić, kiedy nastąpiło zredagowanie pierwszej jego wersji, lecz możliwe, że już w 1733 roku lub na początku 1734 roku, gdyż pod względem zakresu czasowego materiałów, jaki zbiór ten obejmuje, mamy gamę wersji: ograniczonych tylko do roku $1733^{38}$, doprowadzonych do początków 1734 roku $^{39}$, kończących się na roku 1735 lub nawet sejmie pacyfikacyjnym z 1736 roku $^{40}$, i wreszcie - pomijających początek bezkrólewia i zawierających materiały z dowolnych wycinków czasowych ${ }^{41}$. Pod względem zawartości i układu materiałów większość z tych rękopisów prezentuje stosunkowo jednolity model, a różnice między nimi są raczej drobne lub nawet kosmetyczne: jeśli występują, to głównie w obrębie materiałów z 1735 i 1736 roku $^{42}$. Obok nich funkcjonowały także wersje „skrócone” lub niepełne, z opuszczeniem pewnych ważnych i niekiedy licznych dokumentów piśmienniczych ${ }^{43}$.

Mimo pewnych różnic między tymi wersjami i tutaj możemy zauważyć zjawisko powielania rękopisów w jednym środowisku czy nawet przez jedną osobę, co świadczyć może o ich produkcji na zamówienie. Pierwszy przypadek dotyczy trzech egzemplarzy akt bezkrólewia sporządzonych w środowisku marszałka wielkiego koronnego Józefa Wandalina Mniszcha przez jego nieznanego nam z nazwiska pisarza lub sekretarza, o czym świadczy charakter jego pisma, występujący także w innych rękopisach „mniszchowskich”. Dwa egzemplarze są bardzo do siebie zbliżone pod względem zawartości i układu materiałów (lecz nie

38 Rękopisy BZNiO nr 299 (do końca sejmu konwokacyjnego 1733 r.), Muzeum Narodowego w Krakowie (dalej: MNK) nr 32 (do końca sejmu elekcyjnego 1733 r.) i nr 50 (do końca 1733 r.) oraz zniszczone w 1944 r. rękopisy Biblioteki Ordynacji Krasińskich nr 3052 i Biblioteki Załuskich nr 371 („Interregni 1733 acta et scripta”, w Cesarskiej Bibliotece Publicznej w Petersburgu sygn. Razn. F. IV. 25).

39 Rękopisy BUW nr 358, BJ nr akc. 48/86, BB nr 269 i nr 275.

40 Rękopisy BK nr 434, BUW nr 96, AK nr 62/82, BZNiO nr 302, nr 3577, nr 3578 i nr 6611, Archiwum Archidiecezjalnego w Poznaniu, zbiór Biblioteki Wydziału Teologicznego w Poznaniu (dalej: BWTP) nr 175 oraz zniszczony w 1944 r. rękopis Biblioteki Załuskich nr 369 („Acta interregni post fata fata ssmi Augusti II regis Poloniae ab A. 1733 ad 1735”, w Cesarskiej Bibliotece Publicznej w Petersburgu sygn. Razn. F. II. 10).

${ }^{41}$ Rękopisy Biblioteki Polskiej Akademii Nauk i Polskiej Akademii Umiejętności w Krakowie (dalej: BPAU) nr 1106 (obejmuje materiały od października 1733 r. do października 1734 r.), BZNiO nr 300 (obejmuje materiały od sejmu elekcyjnego 1733 r. do 1735 r.) i nr 301 (obejmuje materiały od czerwca do sierpnia 1733 r.).

42 Przykładem mogą być rękopisy BZNiO nr 6611 i AK nr 62/82, zawierające zbliżone materiały, lecz w nieco innym porządku.

${ }^{43} \mathrm{~Np}$. rękopisy BUW nr 358 - tam brakuje np. korespondencji dyplomatycznej prymasa z 1733 r., MNK nr 50 - tam brakuje diariuszy sejmowych i większości korespondencji dyplomatycznej prymasa (w pierwszej części zbiór ten bardzo zbieżny z poprzednim), BK nr 434 tam brakuje np. diariuszy sejmowych, BWTP nr 175 - tam brakuje diariuszy sejmowych $1733 \mathrm{r}$. i w ogóle materiałów z lat 1734-1735 (z wyjątkiem manifestu konfederacji dzikowskiej z 1735 r.). 
identyczne), z których jeden (w dwóch tomach) pozostał w zbiorach Mniszcha, drugi trafił do Karola Wielopolskiego koniuszego koronnego, prywatnie zięcia marszałka. Egzemplarz trzeci natomiast (znajdujący się obecnie w zbiorach Biblioteki Kórnickiej), spisany w połowie tą samą ręką, wykazuje znacznie większe różnice od dwóch pozostałych ${ }^{44}$. Drugi przypadek dotyczy dwóch niemal bliźniaczych egzemplarzy, spisanych w dużej części jedną ręką i zaopatrzonych w kartę tytułową, odtwarzającą niemal wiernie ten sam schemat kompozycyjny i motyw artystyczny ${ }^{45}$. Oczywiście powielane one były także „systemem łańcuszkowym”, nieraz w dłuższym odstępie czasu, czego przykładem jest egzemplarz z 1761 roku, będący bezpośrednim odpisem z egzemplarza sporządzonego ok. 1736 roku dla Karola Wielopolskiego koniuszego koronnego ${ }^{46}$.

O wartości i przydatności akt bezkrólewi — zarówno dla ówczesnych użytkowników, jak i dla obecnych historyków - decydował przede wszystkim dobór zawartych w nich materiałów. Nie był on jednakowy w poszczególnych wersjach, co determinowały zarówno możliwości techniczne dotarcia i zgromadzenia odpowiedniej dokumentacji, jak i czynniki ideowe przyświecające tworzeniu tych zbiorów. Jak już wspomniano - najlepsze możliwości w tym względzie dawała dokumentacja gromadzona przez kancelarie urzędów państwowych. Nie wykluczało to oczywiście sięgania do materiałów pochodzących z innych źródeł, jak np. rękopisów i druków ulotnych ${ }^{47}$.

Pod względem ilości i różnorodności piśmienniczej zebranej dokumentacji zdecydowanie górują akta bezkrólewia lat 1696-1697. Zbiór ten w swojej najbardziej rozbudowanej wersji liczy około $420-430$ dokumentów piśmienniczych ${ }^{48}$ reprezentujących wszystkie rodzaje krążących wówczas materiałów życia publicznego i to w bardzo szerokim zakresie. Dotyczy to szczególnie publicystyki politycznej, której liczbę można szacować na mniej więcej 55 sztuk, wierszy i satyr o tematyce politycznej, korespondencji urzędowej i prywatnej dygnitarzy państwowych (najliczniejszą grupę wśród niej prezentuje korespondencja prymasa Radziejowskiego - ok. 100 sztuk listów, w tym 37 sztuk korespondencji dyplomatycznej). Poza tym znalazły się tam m.in. uchwały i instrukcje dla posłów niektórych sejmików ziemskich, akta zawiązania konfederacji wojewódzkich (województw poznańskiego i kaliskiego, województwa krakowskiego, województwa

44 Są to rękopisy BZNiO nr 3577, 3578 i 6611 oraz BK nr 434.

45 Są to rękopisy BJ nr akc. 48/86 i BUW nr 96 (tutaj mamy do czynienia z redakcją ,zaktualizowaną" o materiały z drugiej połowy 1734 i 1735 r.). Dodać należy że treściowo rękopis BJ nr 48/86 i większa część rękopisu BUW nr 96 są niemal identyczne z rękopisami BB, nr. 269 i 275.

46 Są to rękopisy BZNiO nr. 6611 i 302.

47 Egzemplarze druków i rękopisów ulotnych z lat 1733-1736 znajdują się m.in. w rękopisach BZNiO, nr 3577 i 3578, BUW nr akc. 62 oraz w zbiorze Ignacego Przyjamskiego w Archiwum Głównym Akt Dawnych.

48 Ich liczba jest dość trudna do jednoznacznego określenia ze względu na występujące w tym zbiorze drobne utwory literackie (epigramy, anagramy itp.). 
sandomierskiego, województwa ruskiego, województwa lubelskiego, ziemi czerskiej, województw Prus Królewskich, województwa brzeskiego litewskiego), dwa obszerne diariusze sejmowe (sejmów konwokacyjnego i elekcyjnego), protokoły i postanowienia rad senatu, traktaty zawarte przez władze państwowe ze związkami wojskowymi koronnym i litewskim. Oprócz jednak uniwersału prymasa z 27 czerwca 1696 roku, zwołującego sejmiki i sejm konwokacyjny, zabrakło w tym zbiorze pozostałych aktów urzędowych okresu bezkrólewia, tj. aktu konfederacji generalnej uchwalonej na sejmie konwokacyjnym, uchwały Coequatio iurium stanów W.X. Litewskiego z Korona Polska, artykułów paktów konwentów oraz „suffragiów” oddanych na Augusta II. Ponieważ akta te były wydane drukiem, wydaje się, że pominięcie ich było zabiegiem zamierzonym, podyktowanym ekonomią pracy pisarza. Wyraźnie o tym nadmieniono w przypadku aktu konfederacji generalnej, informując w miejscu, gdzie powinna być umieszczona „ex consequentii ordine”, że ponieważ „była w siedmiu arkuszach wydrukowana tak wielą egzemplarzami, toć supponitur, że się [czytelnikowi] na ów czas dostał jej instrument, a zatym pisać ją tu byłby actus supervacaneus"49.

O tym, że powyższe dylematy nie były odosobnione, świadczy przypadek pisma Uwaga polityczna nad responsem pana posta francuskiego, dostępnego w wersji drukowanej, albowiem w jednym z egzemplarzy akt bezkrólewia 16961697 zrezygnowano z zamieszczania jego odpisu, tłumacząc to w sposób identyczny jak w przypadku aktu konfederacji generalnej, w innym jednak egzemplarzu odpis tego tekstu zamieszczono, przy czym pisarz nie odmówił sobie wyrażenia z tego faktu swego niezadowolenia, nadmieniając, że ,responsu tego copia taka jest summo cum animi mei dolore" 50 .

Pomimo tych opuszczeń zbiór akt bezkrólewia lat 1696-1697 cechuje się największymi zaletami co do reprezentatywności i kompletności dokumentacji. Wydaje się także, że dzieło to jest w pełni oryginalne, oparte na dokumentacji pochodzącej z różnych źródeł i niebędące przeróbką żadnego z istniejących podobnych tematycznie zbiorów. Redaktorzy zadbali w nim o dokumentację dającą przegląd najważniejszych opinii i stanowisk politycznych. Ciekawostką tego zbioru jest też to, że oprócz dokumentów piśmienniczych, szeroko wówczas kolportowanych i rejestrowanych w różnych miscellaneach, znalazły się tam także materiały skądinąd nieznane lub słabo rozpowszechnione. Redaktorzy zadbali o neutralność w doborze materiałów pod kątem opcji politycznych (charakterystyczne jednak, że dość skromnie przedstawiają się tam materiały, a zwłaszcza publicystyka dotycząca kandydatury elektora saskiego Fryderyka Augusta), co można poniekąd wytłumaczyć komercyjnym charakterem przedsięwzięcia. Oczywiście nie jest to dokumentacja kompletna — brakuje tam choćby niektórych często występujących

49 Rękopisy ZO nr 256, s. 311 i BJ nr 3522, k. 230v.

50 Rękopis BJ nr 3522, k. 375v. 
w innych zbiorach z okresu bezkrólewia pism publicystycznych ${ }^{51}$, redaktorzy także nie ustrzegli się zbioru pewnych pomyłek przy klasyfikacji materiałów ${ }^{52}$. Co ciekawe, w dziele tym, oprócz diariusza sejmowego, nie zamieszczono żadnych innych materiałów dotyczących przebiegu sejmu elekcyjnego 1697 roku, chociaż jak wynika ze spisu treści w jednym z egzemplarzy, materiały te były już zebrane $i$ gotowe do wprowadzenia do edycji ${ }^{53}$. Dlaczego tego nie zrobiono, jest dla nas zagadką, lecz możliwe, że stał za tym zamysł redakcyjny, albowiem, jak wiemy z cytowanego już posłowia, redaktor lub redaktorzy tego dzieła planowali opracowanie drugiego tomu, w którym pewne brakujące materiały mogłyby zostać uwzględnione, co nie zostało jednak nigdy zrealizowane.

Zbliżone dane liczbowe i podobny charakter materiałów prezentują „Akta interregni" lat 1733-1736, zawierające w swoich najbardziej rozbudowanych wersjach około 350-355 dokumentów piśmienniczych ${ }^{54}$. Również i tutaj nacisk został położony na dokumentację prezentującą poglądy i stanowiska rywalizujących z sobą obozów politycznych oraz obrazującą przebieg wypadków politycznych; z podstawowych akt urzędowych drukowanych zwyczajowo w okresie bezkrólewia znalazł się tutaj jedynie uniwersał prymasa z 7 lutego 1733 roku zwołujący sejmiki i sejm konwokacyjny. Na dokumentację tutaj zebraną w głównych zarysach składają się: obfita korespondencja urzędowa i prywatna dygnitarzy państwowych, na czele z korespondencją prymasa Teodora Potockiego (około 90 sztuk), protokoły i postanowienia rad senatu, akta związane z czynnościami urzędowymi prymasa, uchwały niektórych sejmików ziemskich, akta zawiązania konfederacji wojewódzkich z lat 1733-1734 (województwa krakowskiego, województwa lubelskiego, województwa sandomierskiego, województwa ruskiego, księstwa oświęcimsko-zatorskiego, województwa podolskiego, województw poznańskiego i kaliskiego) oraz konfederacji generalnej litewskiej 1734 roku, trzy diariusze sejmowe (oprócz sejmów konwokacyjnego i elekcyjnego także sejmu nadzwyczajnego w styczniu 1733 roku, przerwanego na skutek śmierci Augusta II), a wreszcie publicystyka polityczna i inne rodzaje akt służące prezentacji poglądów politycznych (głównie manifesty). Ważnym uzupełnieniem zbioru, występującym w kilku

51 Można tu wskazać takie pisma, jak „Lukubracyja ziemianina na niewczesne na tron polski kandydatów promocyje, jeśli Piast albo obcy in regno eligendus” i „Spowiedź wolności polskiej, która czując się bliską śmierci przed ks. Lechezą jezuitą, kapelanem króla francuskiego, uczyniła".

52 Do zbioru trafiły materiały niezwiązane z bezkrólewiem lat 1696-1697, jak pochodzące z ostatnich miesięcy panowania Jana II Kazimierza pismo „Zwierciadło na elekcyją wystawione królestwa polskiego pro casu abdicationis [anno 1668], w którym Polsce upatrywać potrzeba has necessitates candidatis comitantes".

53 Były to mające być uwzględnione w rozdziale „W samą zaś elekcyją różne transakcyje” (BJ, nr 3522, k. 106) m.in. kazanie sejmowe biskupa płockiego A.Ch. Załuskiego, mowy marszałka poselskiego, prymasa Radziejowskiego, nuncjusza papieskiego, posłów francuskiego i cesarskiego oraz wiadomości ze Lwowa i Gdańska.

54 Rękopisy AK nr 62/82 i BZNiO nr 6611. 
jego wersjach, jest kompilacyjne zestawienie przepisów i zasad prawa publicznego w Polsce w okresie bezkrólewia pt. „Norma agendorum interregni”. W odróżnieniu od „akt interregni” z poprzedniego bezkrólewia oblicze polityczne tego zbioru jest bardziej jednostronne, albowiem większość zgromadzonych tam materiałów reprezentuje stanowisko przychylne kandydaturze Stanisława Leszczyńskiego. Nie może nas to jednak dziwić, zważywszy na genezę tego zbioru i ówczesne nastroje społeczeństwa szlacheckiego, w swojej większości popierającego właśnie Leszczyńskiego. Oczywiście poszczególne wersje tego zbioru to oblicze polityczne akcentowały lub tonowały, chociaż trudno stąd wysnuwać dalej idące wnioski co do przyczyn wprowadzania tych zmian ${ }^{55}$.

Znacznie skromniej przedstawiają się „Akta interregni 1632” redakcji „prymasowskiej", liczące w swojej pełnej wersji ${ }^{56} 222$ dokumenty piśmiennicze, z czego aż 99 stanowią odpisy zdawkowych listów papieża Urbana VIII do senatorów polskich i litewskich z wezwaniem do poparcia kandydatury królewicza Władysława Zygmunta do tronu polskiego. Na pozostałą dokumentację składa się głównie korespondencja prymasa i nieco akt życia publicznego, w tym obszerne „Egzorbitancje na konwokacyi warszawskiej anni 1632 odprawionej od wszystkich stanów namówione", nieliczna korespondencja dygnitarzy państwowych i lauda sejmikowe, bogate akta dotyczące poselstw odprawionych przez posłów państw obcych na elekcji, a wreszcie dwa obszerne diariusze (sejmiku proszowickiego województwa krakowskiego i sejmu elekcyjnego, oczywiście w innej wersji niż diariusz zamieszczony w aktach bezkrólewia J. Sobieskiego). Oprócz jednak „Porządku na sejmie walnym elekcji 1632 r." zabrakło tam innych akt urzędowych, jak zwłaszcza uniwersału prymasa Wężyka z 5 maja 1632 roku oraz aktu konfederacji generalnej uchwalonego na sejmie konwokacyjnym.

Najskromniej prezentują się pod tym względem ,akta interregni” opracowane przez Jakuba Sobieskiego, lecz także pod względem swojej struktury piśmienniczej prezentują one odmienny od pozostałych typ dokumentacji. Nie mamy tu w zasadzie do czynienia z klasycznym zbiorem dokumentów, lecz raczej z kroniką bezkrólewia, złożoną w ogromnej większości z krótkiego diariusza wydarzeń przed sejmami konwokacyjnym i koronacyjnym oraz bardzo obszernych trzech diariuszy sejmów konwokacyjnego 1632 roku, elekcyjnego 1632 roku i koronacyjnego 1633 roku, autorstwa samego Sobieskiego. Znajdujące się tam akta życia publicznego zostały uwzględnione jedynie w przypadku gdy były przedstawiane, omawiane lub były efektem obrad sejmiku wiszeńskiego województwa ruskiego w czerwcu 1632 roku (na którym Sobieski był marszałkiem) lub obrad

55 Przykładem mogą być zbliżone do siebie pod względem zakresu czasowego oraz doboru akt rękopisy BZNiO nr 6611 i AK nr 62/82: w pierwszym z nich zabrakło tak ważnych materiałów skierowanych przeciwko Augustowi II, jak manifesty prymasa Teodora Potockiego i starosty jasielskiego Adama Tarły przeciwko prawomocności jego koronacji w styczniu 1734 r. oraz akt zawiązania konfederacji dzikowskiej 7 listopada $1734 \mathrm{r}$.

56 Rękopis ZAG nr 1. 
trzech wymienionych sejmów. Wyjątkiem jest tutaj testament króla Zygmunta III, umieszczony bez związku z zasadniczą narracją autorską. Oprócz umieszczania poszczególnych dokumentów piśmienniczych w obrębie poszczególnych diariuszy Sobieski część z nich zamieścił w dwóch dużych blokach po zakończeniu diariuszy sejmów elekcyjnego i koronacyjnego jako swego rodzaju załączniki do nich, w zależności od tego, na którym z tych sejmów były procedowane. Zebrane w dziele Sobieskiego akta miały więc bez wyjątku charakter oficjalny lub urzędowy; w dążeniu do kompletności tego rodzaju dokumentacji Sobieski zamieścił także odpis „suffragiów” oddanych na króla Władysława IV w 1632 roku, co było swego rodzaju ewenementem niemającym odpowiednika w innych ,aktach bezkrólewia".

Opracowanie redakcyjne tych zbiorów pozytywnie odróżniało się od innych polskich zbiorów materiałów życia publicznego. W większości zaopatrzone były one w tytuły informujące o tematyce zbioru, zwykle umieszczane na osobnych kartach na początku rękopisu; takowej nie miały tylko egzemplarze „Interregni [post mortem] Joannis III", gdzie tytuł umieszczony został na pierwszej stronie tekstu. Ważną cechą redakcyjnego opracowania tego typu rękopiśmiennych „wydawnictw źródłowych” było nadanie zgromadzonym materiałom logicznego układu. Najprostszym do realizacji ze względów formalnych był oczywiście układ chronologiczny. Najbardziej konsekwentnie zastosowany on został w dziele Sobieskiego, ze względu na jego kronikarską formułę, lecz w innych zbiorach o konsekwentnym stosowaniu go mowy już nie było. Dawał tu o sobie znać przede wszystkim brak dbałości o przestrzeganie tego układu, cechujący w ogóle wszelkie zbiory materiałów życia publicznego, a może też nieumiejętność redagowania tego typu zbiorów. W efekcie tego dochodziło do naruszenia porządku chronologicznego zarówno w przypadku pojedynczych akt (w obrębie dni lub miesięcy) ${ }^{57}$, jak i ich całych bloków, i to z zachwianiem chronologii nawet w obrębie dłuższych okresów ${ }^{58}$. Najkorzystniej pod tym względem prezentują się akta bezkrólewia 1696-1697, gdzie zapanowanie nad porządkiem chronologicznym było łatwiejsze dzięki temu, że materiał tam zebrany został rozdzielony na kilka rozdziałów ${ }^{59}$, jednak i tutaj nie ustrzeżono się przed pewnymi niekonsekwencjami w układzie. To zjawisko miało także swoje obiektywne przyczyny: przyjętą powszechnie for-

57 Przykładem chaosu są tutaj „Acta interregni 1632” redakcji prymasowskiej (ZAG, nr 1), gdzie trudno mówić o jakimś logicznym układzie zawartości, zwłaszcza w pierwszej części rękopisu.

58 Przykładem są „Acta interregni” 1733-1736 w rękopisie BZNiO nr 6611, gdzie po materiałach z października i listopada 1733 r. nastąpiły materiały z lutego i stycznia 1734 r., potem znowu z listopada i października 1733 r., następnie z marca-sierpnia 1734, z lipca i czerwca 1734 r., potem ponownie z lipca, sierpnia i września 1734 r. itp.

59 Zob. dalej s. 203. 
mułę umieszczania obok siebie listu i odpowiedzi nań ${ }^{60}$, co układ chronologiczny rozbijało, jak też scalania pewnych rodzajów akt w wyodrębnionych grupach ze względu na ich tematykę (dotyczyło to zwłaszcza korespondencji dyplomatycznej prymasów z państwami obcymi z zawiadomieniem o śmierci króla, którą wydzielano w dwóch grupach - listów wychodzących i listów przychodzących).

Wydzielanie zgromadzonych materiałów w osobnych częściach lub rozdziałach służyło także lepszej orientacji i poruszaniu się po całym zbiorze. Próba w tym kierunku podjęta została już w aktach bezkrólewia 1632 roku redakcji ,prymasowskiej”, gdzie stworzono rozdziały odpowiadające poszczególnym etapom bezkrólewia („Acta ante convocationem”, „Acta in convocatione”, „Legationes per legatos externeorum principum dictae in electione novi regis Anno D[omi]ni 1632 ad ordines Regni ab iisdemque ordinibus responsiones"), lecz materiałów do poszczególnych rozdziałów nie przydzielono właściwie i konsekwentnie ani nie doprowadzono schematu konstrukcyjnego do końca ${ }^{61}$. Podobny zabieg zastosowano także, równie jednak nie dość konsekwentnie, w kilku egzemplarzach „akt interregni" 1733-1736, pochodzących z kręgu marszałka wielkiego koronnego Józefa Mniszcha (tytuły rozdziałów: „Scripta varia sub interregno proiecta a. 1733”, „Transakcje i skrypta różne po konwokacyi in a. 1733 odprawionej collecta”, „Acta po elekcyi odprawionej a. 1733 collecta") ${ }^{62}$.

Taka konstrukcja wewnętrzna aktów bezkrólewia była jednak regresem w stosunku do tego, co dokonano w zbiorze „Interregnum [post mortem] Joannis III”. Zbiór ten prezentuje nie tylko najbardziej konsekwentnie przeprowadzoną, lecz także najbardziej przemyślaną konstrukcję zawartości, na jaką nie zdobyli się twórcy innych polskich zbiorów materiałów życia publicznego XVII-XVIII wieku. Można go nazwać układem chronologiczno-rzeczowym, w którym materiały zgrupowano w 12 dużych (oczywiście nie zawsze proporcjonalnych pod względem objętości) rozdziałach, o własnych, rozbudowanych tytułach informujących o tematyce i charakterze zawartych w nich materiałów. Można nawet odnieść wrażenie, że takie formułowanie tytułów poszczególnych rozdziałów służyć miało nie tylko potrzebom informacyjnym, lecz miało także cele komercyjne mające zaciekawić potencjalnego odbiorcę różnorodnością zgromadzonych materiałów i zachęcić go do zamówienia dzieła.

Rozdziały te zostały skonstruowane według trzech różnych kryteriów. Najliczniejsza ich grupa (6) zawierała materiały dotyczące zasadniczego przebiegu

60 Por. Waldemar CHORĄŻYCZEWSKI, Zbiór kopiariuszy Andrzeja Opalińskiego (15781588), Studia o bibliotekach i zbiorach polskich (6) 1994, s. 19. Taki właśnie układ zastosowano w późniejszych wersjach akt bezkrólewia 1696-1697.

61 Doskonale zdawał sobie $\mathrm{z}$ tego pisarz tego rękopisu, tytuł rozdziału mającego zawierać akta sejmu konwokacyjnego uzupełniając znamienną uwagą: ,sunt adhuc et alia, quae ante ipsam convocationem sed invicem inter se sunt missa".

62 Rękopisy BZNiO nr. 302, 3577 i 6611. 
bezkrólewia, według jego głównych etapów. W rozdziałach tych znalazły się materiały głównie o charakterze aktowym (korespondencja, uchwały, instrukcje itp.) i objęły one kolejno: 1) okres do sejmików przedkonwokacyjnych, 2) sejmiki przedkonwokacyjne i okres do sejmu konwokacyjnego, 3) sejm konwokacyjny — diariusz obrad, 4) sejm konwokacyjny — mowy poselskie i senatorskie, listy i inne materiały, 5) sejmiki pokonwokacyjne i okres aż do sejmu elekcyjnego, 6) sejm elekcyjny - diariusz obrad. W osobnych dwóch rozdziałach wydzielono materiały dotyczące związków (konfederacji) wojskowych, zawiązanych przez nieopłacone wojsko koronne i litewskie w 1696 roku. Taki zabieg redakcyjny był niezwykle trafnym i uzasadnionym posunięciem, gdyż obie konfederacje mocno odcisnęły się na ówczesnym życiu politycznym, lecz z zasadniczą kwestią wyboru króla związku nie miały. Oczywiście wewnątrz tych rozdziałów ,aktowych” materiały porządkowano według ich chronologii ( jak już wspomniano — nie zawsze jednak konsekwentnie), niekiedy także wydzielano je w osobne grupy ze względu na charakter akt (dotyczyło to np. zbioru korespondencji dyplomatycznej prymasa Radziejowskiego z państwami zagranicznymi z zawiadomieniem o śmierci króla Jana III).

Trzecia wreszcie grupa rozdziałów zawierała materiały prezentujące przede wszystkim poglądy i opinie (teksty publicystyczne i polemiczne, oficjalnie przedstawione na sejmie elekcyjnym rekomendacje kandydatów do tronu, wiersze i satyry, prywatna korespondencja) odnoszące się do najważniejszych problemów bezkrólewia: 1) zerwania sejmu konwokacyjnego („O samym zerwaniu konwokacyjej. Listy z responsami, projekta z replikami i prywatne zdania z innemi transakcjami"), 2) kandydatur do tronu polskiego — pisma o charakterze ogólnym lub omawiające zbiorczo te kandydatury („,O różnych razem kandydatach niby w powszechności. Vaticinia, profecje, prywatne zdania i listy”), 3) kandydatur do tronu polskiego - pisma odnoszące się do poszczególnych kandydatów („O kandydatach w osobności”) — oczywiście osoby poszczególnych kandydatów zostały wydzielone w osobnych „podrozdziałach” (jak np. „Książę de Conty. Listy z responsami, projekta $\mathrm{z}$ replikami i prywatne pro et contra zdania o jego konkurencyi”), 4) przebiegu nadchodzącej elekcji („O przyszłej elekcyjej różne przestrogi do uwagi w projektach i prywatne zdania").

Co warto podkreślić, mimo pewnych potknięć i niejednoznaczności co do zakwalifikowania poszczególnych materiałów do określonych rozdziałów (z czego zresztą redaktorzy zbioru zdawali sobie sprawę, gdyż zmieniali niekiedy w kolejnych egzemplarzach lokalizację niektórych materiałów w poszczególnych rozdziałach), dobór ich był zasadniczo umotywowany względami merytorycznymi. Nigdy też nie doszło do zdublowania tego samego tekstu. Swoboda, z jaką redaktorzy dzieła dokonywali odpowiednich retuszy konstrukcyjnych, zdaje się świadczyć, że dysponowali oni przez cały czas dokumentacją w stanie „,surowym”, złożonym z luźnych akt, ewentualne jakimś rodzajem makiety. 
Często spotykanym elementem w najbardziej dopracowanych pod względem edytorskim egzemplarzach były spisy zawartości rejestrujące dokumenty piśmiennicze $\mathrm{w}$ kolejności występowania ich $\mathrm{w}$ rękopisie. Takie regestry ma kilka egzemplarzy akt bezkrólewi lat 1696-1697 i 1733-1736, każdorazowo z wyszczególnieniem tytułu dokumentu i odwołaniem do właściwej strony lub karty w rękopisie. W przypadku niektórych egzemplarzy akt bezkrólewia 1696-1697 do powyższych elementów dochodziły niekiedy także daty dokumentów ${ }^{63}$ (oczywiście gdy takowe występowały w tekście) oraz ich incipit, co pod względem szczegółowości i precyzyjności opisu było ewenementem w zbiorach podobnego typu. $\mathrm{Z}$ kolei w postaci alfabetycznego indeksu skonstruowany został spis zawartości aktów bezkrólewia 1632 roku Jakuba Sobieskiego, w którym akta ułożono według ich nazw użytych w tekście.

$\mathrm{Z}$ samym jednak sposobem opracowania redakcyjnego poszczególnych dokumentów piśmienniczych (zaopatrywanie ich w tytuły, adnotacje o dacie i miejscu napisania, informacje o treści) nie radzono sobie najlepiej, co zresztą było charakterystyczne dla wszystkich ówczesnych zbiorów materiałów życia publicznego. Nie potrafiono zwłaszcza nadać im jednolitej lub zbliżonej do siebie formuły zapisu - dotyczyło to zwłaszcza tytułów listów, w których bardzo niejednolicie podawano informację o ich autorze i adresacie oraz dacie napisania (ta była uwzględniana lub nie, bardzo dowolnie). Rękopiśmienne „acta interregnorum” prezentują też wszelkie wady rękopiśmiennego powielania tekstów, w tym zwykłe pomyłki pisarskie wynikające z błędnego odczytania tekstu lub popełnione w trakcie jego przepisywania. Nie są od nich wolne nawet stosunkowo najbardziej profesjonalnie wykonane egzemplarze. Interesującym szczegółem jest, że w aktach bezkrólewia 1696-1697 w przypadku odpisów dokonywanych z druków nie tylko informowano o tym fakcie, lecz niekiedy podawano nawet także bliższe dane bibliograficzne druku ${ }^{64}$.

Wszystkie te zbiory (oczy wiście z wyjątkiem „Actorum interregni anni 1632” Jakuba Sobieskiego) są bardzo ubogie w komentarze odredakcyjne, mające za zadanie przybliżyć czytelnikowi tło i okoliczności wydarzeń. W aktach bezkrólewia 1632 roku redakcji ,prymasowskiej” i w niektórych egzemplarzach akt lat 1733-1736 funkcję tę pełniła przedmowa, wyjaśniająca okoliczności śmierci króla Zygmunta III lub pierwszych dni bezkrólewia 1733 roku. Z kolei w aktach bezkrólewia lat 1696-1697 umieszczono na końcu zbioru swego rodzaju posłowie, zatytułowane „Et sic liberrima electio fecit scissam Rempublicam”, w którym ogólnikowo odniesiono się do dalszego rozwoju wypadków w latach 1697-1699, będącego skutkiem rozdwojonego wyniku elekcji — jak już jednak nadmieniono wcześniej, posłowie to pełniło raczej rolę oferty mającej zainteresować i zachęcić

63 Ten element został uwzględniony głównie w spisie treści rękopisu BG nr 1529, a częściowo także w rękopisie AR II nr 33.

${ }^{64}$ Rękopis BB nr 66, k. 391v. 
potencjalnego nabywcę do sfinansowania kolejnego tomu dzieła z materiałami odnoszącymi się do tych wydarzeń niż komentarza historycznego. Nietypową, niewystępującą w innych wersjach akt bezkrólewia 1733-1736, formę zastosował Adam Kempski w przepisanym przez siebie w dużej części egzemplarzu, zaopatrując niektóre akta we własne komentarze historyczne (określone słowem „notandum" ${ }^{65}$.

Na tle polskich zbiorów materiałów życia publicznego z XVII-XVIII wie$\mathrm{ku}$,acta interregnorum” wyróżniały się pozytywnie estetyką wykonania. Wiele z nich sporządzono bardzo starannym, a nawet ozdobnym pismem, z elementami kaligrafii, co dotyczy zwłaszcza akt bezkrólewia 1733-1736 roku ${ }^{66}$. Charakterystycznym zjawiskiem było zaopatrywanie niektórych „edycji” w ozdobne karty tytułowe, a także zamieszczanie w tekście ręcznie wykonanych ilustracji, co w ogóle było ewenementem w polskich zbiorach materiałów życia publicznego. W czterech egzemplarzach akt bezkrólewia $1733-1736^{67}$ ilustracje te przedstawiają koronę królewską, przy czym w trzech przypadkach są one kolorowe. Prawdziwą jednak ,perełką” wśród tych rękopisów jest egzemplarz akt bezkrólewia 1733-1736 przepisany przez Adama Kempskiego - poetę, sekretarza marszałka wielkiego koronnego Franciszka Bielińskiego ${ }^{68}$. Zawiera on sześć rysunków wkomponowanych w tekst (pierwotnie miało być ich osiem, lecz dwie ilustracje mające się znaleźć w końcowej części rękopisu nie zostały już wykonane), prezentujących dość wysoki poziom artystyczny. Trzy z nich są treści alegorycznej, a pozostałe trzy przedstawiają: koronę królewską, herb Korony i Litwy oraz „lilię” burbońską; to wyposażenie artystyczne uzupełniają dwa ozdobne inicjały, rozpoczynające dwa teksty w początkowej części rękopisu.

W niniejszym artykule przedstawiono lub zasygnalizowano istnienie 45 rękopisów „actorum interregnorum” dotyczących trzech bezkrólewi lat 1632, 16961697 i 1733 . Nie jest to liczba mała, co pozwala wyrazić opinię, że mimo swojej ograniczonej dostępności wynikającej z ręcznego sposobu ich powielania akta te odegrały pewną rolę w poszerzaniu, przynajmniej w niektórych kręgach społeczeństwa, wiedzy na temat wydarzeń dziejowych ${ }^{69}$. Starając się ukazać to zagad-

65 Rękopis AK nr 62/82, s. 374, 431, 742, 921.

66 M.in. rękopisy BWTP nr 175, BZNiO nr. 3577 i 3578, AK nr 62/82. Podobnymi walorami odznaczał się także zniszczony rękopis „Actorum interregni” lat 1733-1735 ze zbiorów Biblioteki Załuskich, który J.D. Janocki określił jako „elegantissimus [...] atque praestantissimus codex”, J.D. Janocki, op. cit.

67 Rękopisy BJ nr akc. 48/86, BB nr 269 i nr 275, BUW nr 96.

68 Rękopis AK nr 62/82. Za autorstwem Kempskiego przemawia zbieżność charakteru pisma z rękopisem AK nr 4/4, spisanym bez wątpienia właśnie przez niego.

69 „Acta interregnorum” przede wszystkim znajdowały się w posiadaniu magnatów, jak świadczą zapisy własnościowe na niektórych egzemplarzach, inwentarze biblioteczne z XVIII w. (np. w bibliotekach Sapiehów w Kodniu i Sanguszków w Lubartowie), a także ich obecna przynależność do zbiorów i archiwów rodowych; jednocześnie jednak pojedyncze egzemplarze trafiały w posiadanie szlachty, jak egzemplarz akt bezkrólewia 1632 r. (autorstwa Jakuba Sobieskiego), 
nienie, niedostrzegane jak dotąd w polskiej literaturze naukowej, niniejszy artykuł z pewnością nie udzielił wyczerpującej odpowiedzi na wiele pytań, zwłaszcza dotyczących okoliczności powstania tych zbiorów. Szczególnie intrygująco przedstawiają się te kwestie w odniesieniu do akt bezkrólewia lat 1696-1697 — jednego z najciekawszych polskich zbiorów materiałów życia publicznego z XVII i XVIII wieku. Można mieć tylko nadzieję, że dalsze poszukiwania archiwalne pozwolą wyeliminować przynajmniej niektóre z tych znaków zapytania.

\section{MACIEJ MATWIJÓW}

\section{ACTA INTERREGNORUM - MANUSCRIPT COLLECTIONS OF MATERIALS DOCUMENTING THE HISTORY OF INTERREGNA IN THE POLISH-LITHUANIAN COMMONWEALTH IN THE 17TH AND 18TH CENTURIES*}

\section{Summary}

The most important types of handwritten books in Poland in the 17th-18th centuries were collections of public life materials documenting important political events. Such events in the PolishLithuanian Commonwealth included interregna, lasting from the death of a king to the election of his successor and marked by great intensification of political life. The collections documenting interregna, usually entitled Acta interregnorum, contained both official and private documents, including correspondence of state dignitaries, political writings, resolutions of senate councils, regional assemblies and the parliament as well as parliamentary diaries. Such collections were compiled for the interregna of 1632, 1696-1697 and 1733, with the collection for the 1632 interregnum appearing in two different editions. With the exception of the 1632 interregnum documents, edited by Jakub Sobieski, they appeared in versions differing in terms of the selection and arrangement of their contents, but the differences between the collections were not substantial and did not change the fundamental concepts of such works. The author has identified a total of 45 copies of interregnum files, with the most substantial being the files for the 1733 interregnum and the civil war of 1734-1736 which ensued as a result of the interregnum. The Acta interregnorum were disseminated through copying of the various compilations; they were also commissioned, that it compiled in an organised manner. Unfortunately, with the exception of the collection edited by Jakub Sobieski, we do not know their authors, but the most important role was probably played here by officials associated with the Primates of Poland - Archbishops of Gniezno, who, acting as "interreges", were in charge of the state's policy during the interregna.

KEY WORDS: interregnum, Polish-Lithuanian Commonwealth, public life materials, handwritten books

który według umieszczonej na nim noty proweniencyjnej znajdował się w posiadaniu Antoniego Niemiry, łowczego mielnickiego (możliwe, że tożsamym z występującym w aktach w $1720 \mathrm{r}$. stolnikiem mielnickim) lub były przez nią przepisywane dla swego użytku, jak wzmiankowany wielokrotnie egzemplarz akt bezkrólewia 1733-1736 ze zbiorów Komierowskich.

* The article has been written as part of the research project "Collections of public life materials as a type of handwritten books in Poland in the 17th-18th centuries" financed by the National Science Centre. 